広島の原爆被爆者から発生した甲状腺癌一1958年〜1979年

江 崎 治 夫1

協力者 臨床 安田 克樹 ${ }^{11}$, 武市 宜雄1), 平岡 敬生 ${ }^{2)}$, 伊藤 利夫 ${ }^{11}$

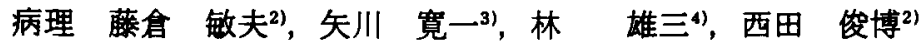

統計 石丸寅之助2)

$$
\begin{aligned}
& \text { 1)広島大学第二外科 } \\
& \text { 2)放射線影響研究所 } \\
& \text { 3)岩手医大第一病理 } \\
& \text { ()広島大学第二病理 }
\end{aligned}
$$

\title{
THYROID CARCINOMA AFTER EXPOSURE TO THE ATOMIC RADIATION OF HIROSHIMA, 1958-1979
}

\section{Haruo EZAKI "), Katsuhiko YASUDA ${ }^{1)}$, Nobuo TAKEICHI ${ }^{1)}$, Toshio HIRAOKA ${ }^{2)}$ \\ Toshio ITO"), Toshio FUJIKURA ${ }^{2)}$, Kan-ichi YAGAWA ${ }^{3)}$, Yuzo HAYASHI") \\ Toshihiro NISHIDA ${ }^{2)}$, and Toranosuke ISHIMARU ${ }^{2)}$ \\ ${ }^{1}$ Second Dept. Surg., Hiroshima Univ. School of Medicine \\ ${ }^{2)}$ Radiation Effects Research Foundation \\ ${ }^{3}$ First Dept. Path., Iwate Med. School \\ ${ }^{4}$ Second Dept. Path., Hiroshima Univ. School of Medicine.}

広島での原爆被爆者からの甲状腺癌の発生を知るため研究を行った。対象は統計処理 を容易ならしめるょう, 性別, 被爆時年龄別, 被爆線量別にあらかしめ定められた固定 集団である放射線影響研究所の寿命調査扗大対象を用い，1958年から1979年までの22年 間に診断，或いは剖検に上り発見された甲状腺癌を調へ，被曝放射線量との関保を明ら

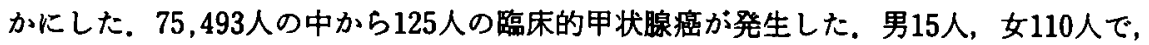
人口10万人対粗年間発生率は男 2.7 , 女12.4で男女共, 線量の增加と共にリスクが増加す る. 若年女性に特に，この傾向が著るしい，期待数に対する钼察数の比 $(\mathrm{O} / \mathrm{E})$ をみると， 男女別です，男女合計でも，線量の增加と共に甲状腺癌が增加する，線型反応について の検定を行うと，女性及び男女合計では線量効果がみとめられた。 又年龄が若い程線量 効果が明らかである.50rad 以上被爆した群の対照群に対する相対性りスクは4.2で，男 女差はないが男性は数が少い為，女性にの及有意である，年踰別では20歳末满のリスク が7.9と高く，統計的に有意である. 統計的に有意な回州係数が求められた20歳末满の女 性の年間 $1 \mathrm{rad}$ 当りのリスクの增加は100万人対約 3.4 である.

同期間に剖埃された4.425人中155人に潜伏癌がみられた．50rad 以上の群の相対的り スクは1.9で有意に高く，O/E 比は男1.6, 女1.8でほほ等しいが，女子にのみ有意であっ た.

東引用語 原爆, 放射線傷害, 甲状腺癌

本論文は第 45 回日本臨休外科医学会, 総会会曼講演と

して発表するるのの一部である。 
朐腺肥大の治展のため上胸部にXX線照射を受けた小 児からの甲状腺癌器生を報告した Hempelmann ${ }^{11} ら$ の研究など，小児に対する放射線による甲状腺癌発生 の可能性, 広島, 長崎の原爆被樭者よりの甲状腺癌の 発生，木爆実倹の fall outによって被瀑した, マーシャ 儿群島の住民からの良性, 覀性甲状腺疾患の多発21な と，放射線による甲状腺癌の発生は確実視されて来て いろ.しかし，甲状腺疾は比交的少い先患であり，且 つ比效的良性の経過をとろので，多数例を確実に把暒 することは困䧼な作業である．著者らは，㧤計学的に 処理し易く，しかも大きい集団を用いて甲状腺癌の発 生を微底的に，確実に，把挃して，放射線による甲状 腺䧺発生を明らかにしようと，この研究を企画した。

\section{1. 明查の対目。}

1958年 1 月に放射線影瑷研究所（以啳, 放影研と略 す）の寿命調查払大対象"1に属する広岛での対象者,

男, 30,942人，女, 45.816人，計76.758人について行っ た。この集団には長崎の被爆者が含まれていて, 両者 を合わせた研究については，別途報告される予定であ
3.

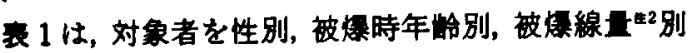
（総組織線量）にみた分布である１，255人の線量不明 者があるが，これは砤㒕な遮蔽状態のため現在の線豆 湘定方式によっては線量の推定ができなかった者であ る.

本研究の対象群から，1958年 1月から1979年12月ま での22年間に発生した甲状腺癌患者を選び出した。 そ して、これを臨床的甲状腺痁 (Clinical thyroid cancer) と潜伏性甲状腺癌 (Occult cancer)（以後，潜伏癌と 略す）とに分けた。潜伏癌は生前に甲状腺癌の記载が なく，㿋がさく，生前に気付かれないと判断したも の155人と，それに他の甲状腺疾患により手術を受け，

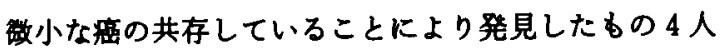
を含んでいる。

Clinical cancer と Occult cancer とは生物学的性質 が異なるのと，調査方法が全く異なるので合わせて考 えることは出来ない，よって本論文では，患者の生命 に影霄のある Clinical cancerを主として調查し, 患者

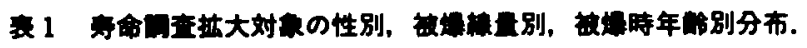

仏島（1958．1.1現在）

\begin{tabular}{|c|c|c|c|c|c|c|c|}
\hline \multirow{2}{*}{$\underset{\mathrm{ATB}}{\mathrm{A} \text { T }}$} & \multicolumn{6}{|c|}{ Tissue Total Dose (rad) } & \multirow{2}{*}{ Total } \\
\hline & Control & $1-49$ & $50 \sim 99$ & $100 \sim 199$ & $200 \sim$ & Unknown & \\
\hline \multicolumn{8}{|c|}{ Male } \\
\hline $0 \sim 9$ & 4629 & 2355 & 142 & 86 & 41 & 57 & 7310 \\
\hline $10 \sim 19$ & 4215 & 2294 & 165 & 102 & 100 & 97 & 6973 \\
\hline $20 \sim 29$ & 1522 & 806 & 63 & 54 & 36 & 75 & 2556 \\
\hline $30 \sim 39$ & 2522 & 1261 & 122 & 67 & 38 & 127 & 4137 \\
\hline $40 \sim 49$ & 3239 & 1713 & 169 & 90 & 58 & 99 & 5368 \\
\hline $50 \sim$ & 2715 & 1551 & 136 & 83 & 43 & 70 & 4598 \\
\hline Total & 18842 & 9980 & 797 & 482 & 316 & 525 & 30942 \\
\hline \multicolumn{8}{|c|}{ Female } \\
\hline $0 \sim 9$ & 4724 & 2415 & 160 & 88 & 50 & 48 & 7485 \\
\hline $10 \sim 19$ & 5492 & 2676 & 264 & 161 & 119 & 333 & 9045 \\
\hline $20 \sim 29$ & 4969 & 2591 & 236 & 134 & 107 & 191 & 8228 \\
\hline $30-39$ & 5071 & 2697 & 188 & 124 & 69 & 74 & 8223 \\
\hline $40-49$ & 4303 & 2289 & 199 & 112 & 71 & 49 & 7023 \\
\hline $50 \sim$ & 3642 & 1911 & 135 & 60 & 29 & 35 & 5812 \\
\hline Total & 28201 & 14579 & 1182 & 679 & 445 & 730 & 45816 \\
\hline $\begin{array}{l}\text { Grand } \\
\text { Total }\end{array}$ & 47043 & 24559 & 1979 & 1161 & 761 & 1255 & 76758 \\
\hline
\end{tabular}

４被爆時年龆 
に影幚のある Clinical cancer を主として調査し, 患者 の生命に殆んど関係がないとされる Occult cancer に ついては付言する形式にした。

注 1. Life span study (LSS) extended Sample（寿 命調查扗大対象)

放射線影研究所（旧，原爆侮害調查委員会）にて，“原 爆の急性售による死を免れた人々は，非被爆者と同様な 寿命を保ち得るかどらがを調査する目的で，1950年10月， 厇島市内在住者から調査対象集団として近距部被爆者群 に，性、年秢をマッ千させた固定対象集団を作った。その後， 各人の推定被爆線量か測定されたので，距離別に分けてい たものが，被爆線量別に改められ、これを寿命調査対象と名 つけられた. 1961年に，死亡等による対象人数の减少を補5 ため近距離被爆者の数を追加して，寿命調查払大対象とし ている，表 1 は，Jan，1，1958現在に於ける実对象人員で, 棇計76,758人である. 対象に属する人, 全員について重場登 绿，組䎦登録，剖見報告，死亡猃断書等の記録が集められて いる. 寿命調査拡大対象は1961年に決められたるのである か，前述の如く，それ以前から調㚗されているので，1958年 に始まったこの調查の対象も，実際上，寿命調査执大対象と 踊积してもよい。

注 2.T65D：1966年放影研では，被爆距離及び，遮蔽 状況に基ついて，各個人の受けた推定ガンマ線量及び 中性子線量を別々に测定している3゙．甲状腺の組繳 量はKerrの提案した甲状腺組渽線量/Kerma 線量变 奐保数の公式を用いて，各個人每に計算した。

表 $2 に 4$ 総線量区分別にみたガンマ線，中性子線， 総線量の平均值を示した。総線量の增加と共に，中性 子線の比率が少しずつ高くなっている.最近になって，

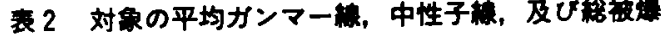
甲状腺線量別分布

厇島（1958-1979）

\begin{tabular}{c|c|c|c|c|c}
\hline & \multicolumn{4}{|c|}{ Thyroid tissue total dose (rad) } & \multirow{2}{*}{ Total } \\
\cline { 2 - 6 } & Control & $1 \sim 49$ & $50 \sim 99$ & $100 \sim$ & \\
\hline No of subject & 47042 & 24555 & 1979 & 1917 & 75493 \\
& & Average dose & & \\
\hline Dr & 0.0 & 8.5 & 59.9 & 165.2 & - \\
\hline Dn & 0.0 & 1.2 & 10.1 & 35.5 & - \\
\hline Total & 0.0 & 9.7 & 70.0 & 200.7 & - \\
\hline
\end{tabular}

D r : ガンマ線量, Dn：中性子線量

放射線量の誤りが指摘されているので゙，将来甲状腺 組織線量す変更されるかもしれない。しかし，本研究 は，被爆線量の絶対値の影䇺を論ずるすのではなく， 線量間のリスクの比較を主としたものであるから，線 量が将来改訂されてす結論が大きく变るとは考えられ ない。

広島の腫瘍登録，組部登録，死亡診断書，剖検記録， 以前施行された放影研に於ける甲状腺癌の特別調查記 録（潜伏癌に対する研究を除く）及び対象群の一部に 対して 2 年毎に行われている検診結果（成人健康調 查), 更に広島大学医学部第二外科教室と厇島大学原医 研外科部門に於ける甲状腺癌と診断された症例を集め た.

こうして集められた症例は332人（粗資料）で，表 3 に資料源別の症例数の分布を示した，Total は重複を 除いた絶対数で示している，畽湯登録によるるのが最 も多かったが，これには甲状腺癌ではないるのが多数 含まれ，臨床的甲状腺癌の占める率は38.6\%にすぎず，

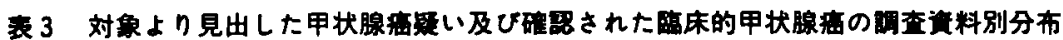

広島（1958一1979）

\begin{tabular}{l|c|c|c}
\hline \multicolumn{1}{c|}{ Source of Screening } & $\begin{array}{c}\text { No. of Possibe } \\
\text { Thyroid Cancer } \\
\text { (A) }\end{array}$ & $\begin{array}{c}\text { No. of Clinical } \\
\text { Thyroid Cancer } \\
(\mathrm{B})\end{array}$ & B/A $\times 100$ \\
\hline $\begin{array}{l}\text { Departments of Surgery in } \\
\text { Hiroshima Medical School }\end{array}$ & 73 & 67 & 91.8 \\
\hline $\begin{array}{l}\text { ABCC/RERF* Previous Special } \\
\text { Thyroid Cancer Studies }\end{array}$ & 94 & 58 & 61.7 \\
\hline Tumor Registry & 280 & 108 & 38.6 \\
\hline Tissue Registry & 34 & 32 & 94.1 \\
\hline ABCC/RERF Pathology Records & 195 & 40 & 20.5 \\
\hline Death Certificate \& Others & 17 & 13 & 76.5 \\
\hline Total No. of Cases Screened & 332 & 136 & 41.0 \\
\hline
\end{tabular}

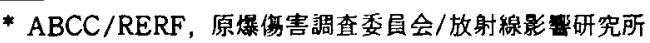


広大外科のものの，臨床的甲状腺癌の占める率は $91.8 \%$ と高かった，碓認された臨床的甲状腺癌の半数 は著者の数室で診㞠したすのであった。

各資料の間には重複例が多いが，それぞれ独立して 資料を集め，これらを総合して再娭討を加えた。 全症 例について，各医療機関に問合わせるか，出向して病 理標本を含めた資料を集め，それで不充分な時には， 診療した医師より，診療時の様子を聞いて診断を確め た.

また，生存者で診断の㖟昧な症例に対しては，厷大 病院か放影研に来院を求めて診断を確実にした，病理 学的に甲状腺癌とされているるのの中，潜伏癌である かどらかは，各々の症例の検討によって行った，個々 の症例が癌であるか，どうかの最終の決定は，江崎が 行った。標本を入手し得たるのの病理学的分類は甲状 腺病理学を専門とする病理学者の協力を得て再検討を 加之て，分類法は，甲状腺外科強討会の“甲状腺癌取 报い規約”によった。

粗資料から，上記の基準に基づいた甲状腺癌の確認 には，1980年から，1982年に及ぶ約 2 年半を要した。

以上の手段により332人を検討した結果は，表 4 に示 すよ5に136人は臨床症状を伴った甲状腺癌，159人は 潜伏癌，37人は甲状腺癌ではないと判断された，潜伏 癌の多くは，放影研での剖検によって発見されたりの である.臨床的の甲状腺癌とした136人を診断の確実性

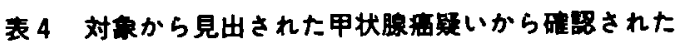
馀别分布

\begin{tabular}{c|r|c}
\multicolumn{2}{c}{ 広島 $(1958-19$} \\
\hline $\begin{array}{c}\text { Classification } \\
\text { of Diagnosis }\end{array}$ & No. & $(\%)$ \\
\hline Clinical thyroid Ca. & 136 & $(41.0)$ \\
\hline Occult thyroid $\mathrm{Ca}$. & 159 & $(47.9)$ \\
\hline Other than thyroid $\mathrm{Ca}$ & 37 & $(11.1)$ \\
\hline Total & 332 & $(100.0)$ \\
\hline
\end{tabular}

\section{表 5 監床的甲状腺艘と晾断された症例の碃实度分布}

広島 $(1958-1979)$

\begin{tabular}{c|r|c}
\hline $\begin{array}{c}\text { Certainty of } \\
\text { Diagnosis }\end{array}$ & No. & $(\mathscr{6})$ \\
\hline Definite & 103 & $(75.7)$ \\
\hline Probable & 32 & $(23.5)$ \\
\hline Possible & 1 & $(0.8)$ \\
\hline Total & 136 & $(100.0)$ \\
\hline
\end{tabular}

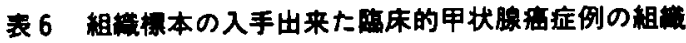 学的分布}

厇島 $(1958-1979)$

\begin{tabular}{l|c|c|c|c}
\hline \multirow{2}{*}{ Morphologic type } & \multicolumn{4}{|c}{ Tissue total dose (rad) } \\
\cline { 2 - 5 } & Control & $1 \sim 49$ & $50 \sim$ & Total \\
\hline Papillary carcinoma & 43 & 38 & 16 & 97 \\
$(100.0)$ & $(90.5)$ & $(88.9)$ & $(94.2)$ \\
\hline Sclerosing carcinoma & 0 & 0 & 0 & 0 \\
\hline Follicular carcinoma & 0 & $\left(\begin{array}{c}2 \\
4.8\end{array}\right)$ & $\left(\begin{array}{c}1 \\
5.6)\end{array}\right.$ & $(2.9)$ \\
\hline Epidermoid carcinoma & 0 & $\left(\begin{array}{c}1 \\
2.4\end{array}\right)$ & 0 & $\left(\begin{array}{c}1 \\
1.0)\end{array}\right.$ \\
\hline Anaplastic carcinoma & 0 & $\left(\begin{array}{c}1 \\
2.4\end{array}\right)$ & $\left(\begin{array}{c}1 \\
5.6\end{array}\right)$ & $(2.0)$ \\
\hline Medullary carcinoma & 0 & 0 & 0 & 0 \\
\hline \multicolumn{1}{|c|}{ Total } & 43 & 42 & 18 & 103 \\
\hline
\end{tabular}

( ) shows percentage

に従って分類したのが表 5 である.103人は病理標本を 再検して組織型を分類出来たりのであり，32人は標本 の入手は出来なかったが，医学記録から甲状腺癌と江 崎が判定したもので, probable とした。 1 人は, 死亡 診断書のみが残っており，それには甲状腺癌となって いるが，その他の手かがが全く得られず，その診断 を採用して甲状腺癌とした不確実例であり，possible と分類した。

表 6 に，病理学的に確認された臨床的甲状腺癌の組

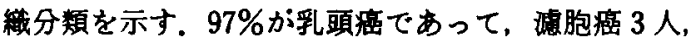
扁平上皮癌 1 人, 未分化癌 1 人である. control はすべ て乳頭癌で，他の型はすべて被爆者であった。しかし， 乳頭癌以外の症例が少いので，線量別にみた分布の差 異について推計学的意羲をつけることが出来なかっ た.

\section{2. 成繒}

以上述べてきた集団を対象とした甲状腺癌の発生 と，被爆線量との関係を解析した成績を示す。

この中，被爆線量不明のすのと，1958年 1 月以前に 甲状腺癌と診断されている者, 合計11人を除いて, 75,493 人の対象の中から，125人の臨床的甲状腺癌か溌 生し，その発生率と被爆線量との関係について解析し た.

表 7 k125名の甲状腺癌患者の分布を男女別，甲状腺 癌を診断した初診時の年龄別, 被爆線量別の分布を示 した. 男15名，女110名で，年龄分布では40〜59歳が最 む多く，1 rad以上の線量を受けた者は70名，対照は 55例であった。 


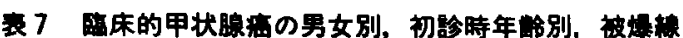
别分布

広島（1958－1979）

\begin{tabular}{c|c|r|r}
\hline Items & & No. & \multicolumn{1}{c}{$\%$} \\
\hline \multirow{4}{*}{ Sex } & Male & 15 & 12.0 \\
\cline { 2 - 4 } & Female & 110 & 88.0 \\
\hline \multirow{4}{*}{$\begin{array}{c}\text { Age at } \\
\text { 1st exam. }\end{array}$} & $<20$ & 0 & 0.0 \\
\cline { 2 - 4 } & $20 \sim 39$ & 35 & 28.0 \\
\cline { 2 - 4 } & $40 \sim 59$ & 53 & 42.4 \\
\cline { 2 - 4 } & $60 \sim 79$ & 32 & 25.6 \\
\cline { 2 - 4 } & $80 \sim$ & 5 & 4.0 \\
\hline \multirow{4}{*}{$\begin{array}{c}\text { Tissue } \\
\text { Total dose } \\
\text { (rad) }\end{array}$} & $100 \sim$ & 10 & 8.0 \\
\cline { 2 - 4 } & $50 \sim 99$ & 9 & 7.2 \\
\cline { 2 - 4 } & $1 \sim 49$ & 51 & 40.8 \\
\hline & Control & 55 & 44.4 \\
\hline Total & - & 125 & 100.0 \\
\hline
\end{tabular}

表 8 は, 男女別, 線量別にみた甲状腺癌の人口10万 対の粗年間発生率である。調查期間22年間に, 死亡例 と甲状腺癌の発生があるので，死亡や癌発生後の観察 年数を除いた person yearを各個人について計算し， その person year に対する発生率をみると，男女共， 線量の增加と共に臨床的甲状腺癌のリスクが増加する 傾向が認められた。男性について, 高線量群の增加が

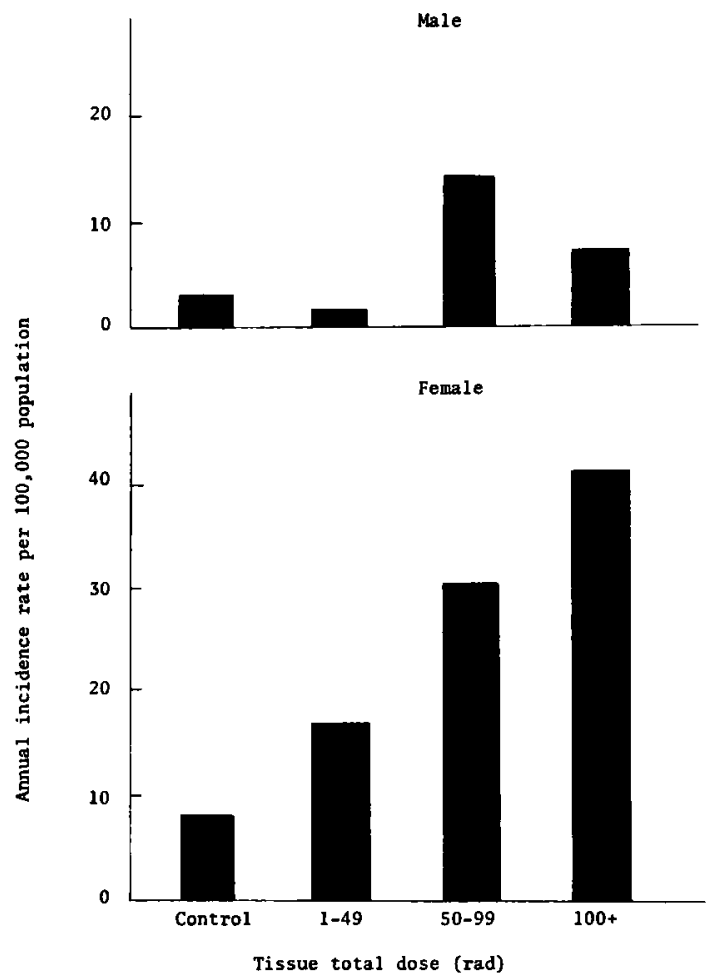

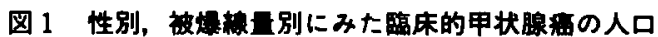
対10万の粗年间発生

広島（1958-1979）

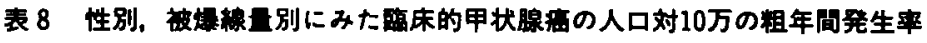

広島（1958-1979）

\begin{tabular}{c|c|c|c|c|c}
\hline \multirow{2}{*}{ Dose range } & \multicolumn{3}{|c|}{ Thyroid tissue total dose (rad) } & \multirow{2}{*}{ Total } \\
\cline { 2 - 5 } & Control & $1 \sim 49$ & $50 \sim 99$ & $100 \sim$ & \\
\hline
\end{tabular}

\begin{tabular}{l|c|r|r|r|r}
\hline No. of subject & 18842 & 9977 & 797 & 798 & 30414 \\
\hline Average dose & 0.0 & 9.1 & 71.2 & 205.6 & - \\
\hline PY* & 351551 & 184857 & 14259 & 14245 & 564912 \\
\hline No. of cases & 9 & 3 & 2 & 1 & 15 \\
\hline Rate $\left(10^{-5}\right)$ & 2.6 & 1.6 & 14.0 & 7.0 & 2.7 \\
\hline
\end{tabular}

Female

\begin{tabular}{l|c|c|r|r|r}
\hline No. of subject & 28200 & 14578 & 1182 & 1119 & 45079 \\
\hline Average dose & 0.0 & 10.1 & 69.2 & 197.2 & - \\
\hline PY & 554902 & 284995 & 23143 & 21840 & 884880 \\
\hline No. of cases & 46 & 48 & 7 & 9 & 110 \\
\hline Rate $\left(10^{-5}\right)$ & 8.2 & 16.8 & 30.2 & 41.2 & 12.4 \\
\hline
\end{tabular}

PY* : person year 
著しくないが，数が少いためにそらなったすので，㑯 向としては女性同粎線旦と共に增加している，图1は これを罒にしたすのである。

表 9 は，被爆時年龄を細分化して，年間発生率をみ たるのである．男性では例数が少いので傾向が明らか でないが，女性では各被爆時年龄共，線量の増加と共 にリスクが高くなり，若年被爆者で特に線量の増加と 共に、リスクが高くなる傾向が認められた。

亯10 と表11は，観察数と期待数を出し，期待数に対 する観察数の比 $(\mathrm{O} / \mathrm{E})$ を求め検討している. 期待数に ついては，珄及び被爆時年龄の構成差に上る影部を除 くための標準化を行っている.

表10で O/E 比をみると，男女別にしても，男女合計 でも何れる線量の増加と共に甲状腺癌が增加する。こ れを線旦效果があるか否か Mantel の統計的手法で，
線型反応についての検定を行ってみると，女性及び男 女合計では，梳計的に有意な関連が認められた，男性 では，甲状腺癌の発生が少いため，関連を証明出来な かった.

表11は，これを被爆時年龄別に分けたるのである。 被爆時年龄20歳末満，20－39歳，40嵅以上に分け，性 に対する標準化を行った．何れの年龄に於いてる被爆 線量の増加之共に $\mathrm{O} / \mathrm{E}$ 比の増加傾向を認め, 特に20歳 以下に著しかった，線量奻果を示す線型反応に対する 娭定では，被爆時年龄20歳以下では推計学的に明らか に有意で，20－39歳で suggestive，40歳以上では明ら かでなく，年龄が若い程線量効果が明瞭である。

表12は，50rad 以上被爆した群の対照群に対する甲 状腺癌発生の相対的リスクと，その統計的有意差を検 定したものである．性と被煤時年龄を標準化した揚合

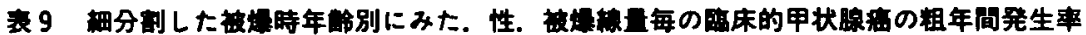
広島 (1958-1979)

\begin{tabular}{|c|c|c|c|c|c|c|}
\hline \multirow{2}{*}{ Age ATB } & & \multicolumn{4}{|c|}{ Tissue Total Dose (rad) } & \multirow{2}{*}{ Total } \\
\hline & & Control & $1-49$ & $50 \sim 99$ & $100 \sim$ & \\
\hline \multicolumn{7}{|c|}{ Male } \\
\hline \multirow{3}{*}{$0-9$} & PY & 100210 & 51009 & 3067 & 2647 & 156933 \\
\hline & Case & 1 & 0 & 0 & 1 & 2 \\
\hline & Rate $\left(10^{-5}\right)$ & 1.00 & .00 & .00 & 37.78 & 1.27 \\
\hline \multirow{3}{*}{$10 \sim 19$} & PY & 90006 & 48884 & 3494 & 4185 & 146569 \\
\hline & Case & 3 & 0 & 1 & 0 & 4 \\
\hline & Rate $\left(10^{-5}\right)$ & 3.33 & .00 & 28.62 & .00 & 2.73 \\
\hline \multirow{3}{*}{$20 \sim 29$} & PY & 31554 & 16403 & 1322 & 1851 & 50930 \\
\hline & Case & 3 & 0 & 0 & 0 & 3 \\
\hline & Rate $\left(10^{-5}\right)$ & 9.51 & .00 & .00 & 0.00 & 5.89 \\
\hline \multirow{3}{*}{$30-39$} & $\mathbf{P Y}$ & 48864 & 24389 & 2399 & 2011 & 77663 \\
\hline & Case & 1 & 1 & 0 & 0 & 2 \\
\hline & Rate $\left(10^{-5}\right)$ & 2.05 & 4.10 & .00 & .00 & 2.58 \\
\hline \multirow{3}{*}{$40 \sim 49$} & PY & 53129 & 28279 & 2664 & 2257 & 86329 \\
\hline & Case & 1 & 1 & 0 & 0 & 2 \\
\hline & Rate $\left(10^{-5}\right)$ & 1.88 & 3.54 & .00 & .00 & 2.32 \\
\hline \multirow{3}{*}{$50-$} & PY & 27989 & 15893 & 1313 & 1293 & 46488 \\
\hline & Case & 0 & 1 & 1 & 0 & 2 \\
\hline & Rate $\left(10^{-5}\right)$ & .00 & 6.29 & 76.16 & .00 & 4.30 \\
\hline \multirow{3}{*}{ Total } & PY & 351552 & 184857 & 14259 & 14244 & 564912 \\
\hline & Case & 9 & 3 & 2 & 1 & 15 \\
\hline & Rate $\left(10^{-5}\right)$ & 2.56 & 1.62 & 14.03 & 7.02 & 2.66 \\
\hline
\end{tabular}

\begin{tabular}{|c|c|c|c|c|c|c|}
\hline \multirow{2}{*}{ Age ATB } & & \multicolumn{4}{|c|}{ Tissue Total Dose (rad) } & \multirow{2}{*}{ Total } \\
\hline & & Control & $1-49$ & $50-99$ & $100 \sim$ & \\
\hline \multicolumn{7}{|c|}{ Female } \\
\hline \multirow{3}{*}{$0 \sim 9$} & PY & 103048 & 52737 & 3445 & 2994 & 162224 \\
\hline & Case & 4 & 5 & 1 & 1 & 11 \\
\hline & Rate $\left(10^{-s}\right)$ & 3.88 & 9.48 & 29.03 & 33.40 & 6.78 \\
\hline \multirow{3}{*}{$10 \sim 19$} & PY & 118766 & 57500 & 5626 & 5903 & 187795 \\
\hline & Case & 8 & 9 & 2 & 4 & 23 \\
\hline & Rate $\left(10^{-5}\right)$ & 6.74 & 15.65 & 35.55 & 67.76 & 12.25 \\
\hline \multirow{3}{*}{$20 \sim 29$} & PY & 105998 & 55155 & 4984 & 4920 & 171057 \\
\hline & Case & 16 & 6 & 1 & 1 & 24 \\
\hline & Rate $\left(10^{-5}\right)$ & 15.10 & 10.88 & 20.06 & 20.33 & 14.03 \\
\hline \multirow{3}{*}{$30-39$} & PY & 104156 & 55255 & 3903 & 3771 & 167085 \\
\hline & Case & 6 & 12 & 1 & 2 & 21 \\
\hline & Rate $\left(10^{-5}\right)$ & 5.76 & 21.72 & 25.62 & 53.04 & 12.57 \\
\hline \multirow{3}{*}{$40 \sim 49$} & PY & 80170 & 42132 & 3572 & 3191 & 129065 \\
\hline & Case & 9 & 11 & 1 & 1 & 22 \\
\hline & Rate $\left(10^{-5}\right)$ & 11.23 & 26.11 & 28.00 & 31.34 & 17.05 \\
\hline \multirow{3}{*}{$50 \sim$} & PY & 42763 & 22216 & 1612 & 1063 & 67654 \\
\hline & Case & 3 & 5 & 1 & 0 & 9 \\
\hline & Rate $\left(10^{-6}\right)$ & 7.02 & 22.51 & 62.04 & .00 & 13.30 \\
\hline \multirow{3}{*}{ Total } & PY & 554901 & 284995 & 23142 & 21842 & 884880 \\
\hline & Case & 46 & 48 & 7 & 9 & 110 \\
\hline & Rate $\left(10^{-5}\right)$ & 8.29 & 16.84 & 30.25 & 41.21 & 12.43 \\
\hline \multicolumn{2}{|c|}{ Both sexes PY } & 906453 & 469852 & 37401 & 36086 & 1449792 \\
\hline & Case & 55 & 51 & 9 & 10 & 125 \\
\hline & Rate $\left(10^{-5}\right)$ & 6.07 & 10.85 & 24.06 & 27.71 & 8.62 \\
\hline \multicolumn{7}{|c|}{ Standardized } \\
\hline inciden & rate $\left(10^{-5}\right)$ & 5.62 & 10.02 & 25.42 & 20.30 & 7.92 \\
\hline \multicolumn{2}{|c|}{ Standardized population } & $10000 \mathrm{p}$ & ppulation & or each & ge ATB & group \\
\hline
\end{tabular}




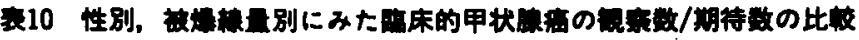

忩岛 (1958-1979)

\begin{tabular}{|c|c|c|c|c|c|c|}
\hline & \multicolumn{5}{|c|}{ Tissue total dose (rad) } & \multirow{3}{*}{$\begin{array}{l}\text { Test for } \\
\text { linearity } \\
x^{2} \text { (1) }\end{array}$} \\
\hline & Control & $1 \sim 49$ & $50 \sim 99$ & $100 \sim$ & Total & \\
\hline $\begin{array}{l}\text { Average dose } \\
\text { (rad) }\end{array}$ & 0 & 9.7 & 70.0 & 200.7 & - & \\
\hline \multicolumn{7}{|c|}{ Total } \\
\hline No. of subjects & 47042 & 24555 & 1979 & 1917 & 75493 & \multirow{4}{*}{$\mathrm{p}<0.001^{* * *}$} \\
\hline Observed $(\mathrm{O})$ & 55 & 51 & 9 & 10 & 125 & \\
\hline Expected $*(E)$ & 78.05 & 40.53 & 3.28 & 3.14 & 125.00 & \\
\hline$O: E$ & 0.70 & 1.26 & 2.74 & 3.18 & 1.00 & \\
\hline \multicolumn{7}{|c|}{ Male } \\
\hline No. of subjects & 18842 & 9977 & 797 & 798 & 30414 & \multirow{4}{*}{$\mathrm{p}>0.10^{2.70}$ N.S } \\
\hline Observed (E) & 9 & 3 & 2 & 1 & 15 & \\
\hline Expected * (E) & 9.30 & 4.90 & 0.40 & 0.40 & 15.00 & \\
\hline $\mathrm{O} / \mathrm{E}$ & 0.97 & 0.61 & 5.00 & 2.50 & 1.00 & \\
\hline \multicolumn{7}{|c|}{ Female } \\
\hline No. of subjects & 28200 & 14578 & 1182 & 1119 & 45079 & \multirow{4}{*}{$p<0.001^{23.81 *}$} \\
\hline Observed $(\mathrm{O})$ & 46 & 48 & 7 & 9 & 110 & \\
\hline Expected $*(E)$ & 68.75 & 35.63 & 2.88 & 2.74 & 110.00 & \\
\hline$O / E$ & 0.67 & 1.35 & 2.43 & 3.28 & 1.00 & \\
\hline
\end{tabular}

* Expected number: Adjusted for age ATB

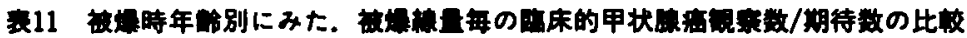

\begin{tabular}{|c|c|c|c|c|c|c|}
\hline & & & & & \multicolumn{2}{|c|}{ 広岛（1958－1979） } \\
\hline & \multicolumn{5}{|c|}{ Tissue total dose (rad) } & \multirow{3}{*}{$\begin{array}{l}\text { Test for } \\
\text { linearity } \\
x^{2} \text { (1) } P\end{array}$} \\
\hline & Control & $1-49$ & $50 \sim 99$ & $100 \sim$ & Total & \\
\hline $\begin{array}{c}\text { Average dose } \\
\text { (rad) }\end{array}$ & 0 & 9.7 & 70.0 & 200.7 & - & \\
\hline \multicolumn{7}{|c|}{ Age ATB: Under 20} \\
\hline No. of subjects & 19060 & 9738 & 731 & 745 & 30274 & \multirow{4}{*}{$p<0.001^{34 * *}$} \\
\hline Observed $(O)$ & 16 & 14 & 4 & 6 & 40 & \\
\hline Expected $*(E)$ & 25.27 & 12.69 & 1.02 & 1.02 & 40.00 & \\
\hline$O / E$ & 0.63 & 1.10 & 3.92 & 5.88 & 1.00 & \\
\hline \multicolumn{7}{|c|}{ Age ATB : $20 \sim 39$} \\
\hline No. of subjects & 14084 & 7355 & 609 & 627 & 22675 & \multirow{4}{*}{$\mathrm{p}: \stackrel{2.88}{0.10 \sim 0.05}$} \\
\hline Observed (O) & 26 & 19 & 2 & 3 & 50 & \\
\hline Expected ${ }^{*}(E)$ & 31.03 & 16.30 & 1.32 & 1.35 & 50.00 & \\
\hline $\mathrm{O} / \mathrm{E}$ & 0.84 & 1.17 & 1.52 & 2.22 & 1.00 & \\
\hline \multicolumn{7}{|c|}{ Age ATB : 40 and over } \\
\hline No. of subjects & 13898 & 7462 & 639 & 545 & 22544 & \multirow{4}{*}{$\mathrm{p}>0.10^{1.91} \mathrm{~N} . \mathrm{S}$} \\
\hline Observed (O) & 13 & 18 & 3 & 1 & 35 & \\
\hline Expected $^{*}(E)$ & 21.75 & 11.54 & 0.94 & 0.77 & 35.00 & \\
\hline$O / E$ & 0.60 & 1.56 & 3.19 & 1.30 & 1.00 & \\
\hline
\end{tabular}

* Expected unmber : Adjusted for sex 


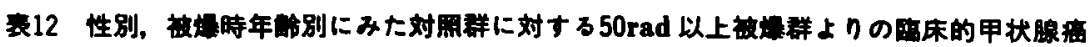
発生の相対性リスク

広岛 (1958-1979)

\begin{tabular}{|c|c|c|c|c|c|}
\hline $\begin{array}{l}\text { Dose } \\
\text { group }\end{array}$ & $\begin{array}{l}\text { No. of } \\
\text { subjects }\end{array}$ & $\begin{array}{l}\text { No. of } \\
\text { case }\end{array}$ & $\begin{array}{l}\text { Statistical } \\
\text { test }^{*} \\
\chi^{2}(\mathrm{df}=1) \\
\end{array}$ & $\begin{array}{l}\text { Standardized } \\
\text { relative } \\
\text { risk }\end{array}$ & $\begin{array}{l}95 \% \\
\text { Confidence } \\
\text { limits }\end{array}$ \\
\hline \multicolumn{6}{|c|}{ Total (adjusted for sex and age ATB) } \\
\hline $50 \mathrm{rad}+$ & 3896 & 19 & 31.96 & 4.2 & $(6.9-2.6)$ \\
\hline Control & 47042 & 55 & $\mathrm{p}<0.001^{* * *}$ & 1.0 & \\
\hline \multicolumn{6}{|c|}{ Male (adjusted for age ATB) } \\
\hline $50 \mathrm{rad}+$ & 1595 & 3 & 2.92 & 4.0 & $(19.3-0.8)$ \\
\hline Control & 18842 & 9 & $\mathrm{p}<0.10$ Sugg & 1.0 & \\
\hline \multicolumn{6}{|c|}{ Female (adjusted for age ATB) } \\
\hline $50 \mathrm{rad}+$ & 2301 & 16 & 26.89 & 4.3 & $(7.3-2.5)$ \\
\hline Control & 28200 & 46 & $\mathrm{p}<0.001^{* * *}$ & 1.0 & \\
\hline \multicolumn{6}{|c|}{ Age ATB : $0 \sim 19$ (adjusted for sex) } \\
\hline $50 \mathrm{rad}+$ & 1476 & 10 & 32.32 & 7.9 & $(16.1-3.9)$ \\
\hline Control & 19060 & 16 & $\mathrm{p}<0.001^{* * *}$ & 1.0 & \\
\hline \multicolumn{6}{|c|}{ Age ATB : $20 \sim 39$ (adjusted for sex) } \\
\hline $50 \mathrm{rad}+$ & 1236 & 5 & 1.83 & 2.2 & $(7.1-0.7)$ \\
\hline Control & 14084 & 26 & $\mathrm{p}>0.10$ N.S. & 1.0 & \\
\hline \multicolumn{6}{|c|}{ Age ATB : 40 (adjusted for sex) } \\
\hline $50 \mathrm{rad}+$ & 1184 & 4 & 4.50 & 4.0 & $(14.2-1.1)$ \\
\hline Control & 13898 & 13 & $\mathrm{p}<0.05^{*}$ & 1.0 & \\
\hline
\end{tabular}

* Mantel-Haenszel procedure

の相対的リスクは, 4.2(95\%信頼限度6.9 2.6)であっ た. 男女別にみると，リスクに男女差はないか，男性 では数が少いため統計的に有意でなかった。被爆時年 龄別にみると、20歳未満では,リスクが7.9と最る高く， 20〜39歳では2.2，40歳以上で4.0であり，20藏末満の 群にのみ統計的に有意差を認めた。

なお，資料がモデルに通合し，統計的に，有意な回 㷌係数が求められた20葴末満の女性についてのみ 1 $\mathrm{rad}$ 当りのリスクの增加を計算すると100万人対年間 䄪3.4であった。

続いて潜伏癌について述べる。

寿命調查払大対象に属し，期間中に剖検され，線量 が測定されている4.425人中155人 (3.5\%)に潜伏癌が みられた，潜伏癌の定義は，甲状腺外科検討会の规約 によるものではなく, 剖検前に甲状腺腫の既往がなく， 恐らく生前の触診にて気付かれないであろうと判断さ

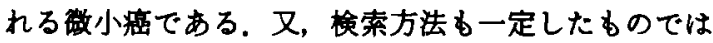
なく，普通の剖検により発見されたすので，例えば1957
年一1968年にかけて調查されたもの（剖検時の甲状腺 癌有病率の研究のため $2 \sim 3 \mathrm{~cm}$ の巾に切断して調べ ている)は含まれていない，従って，資料は，決まっ た方法で調べていないので，絶対值を求めるのに適し ていない，しかし，被爆線量の差による影䇾を比較す ることは出来る。

表13は, 50 rad 以上の被爆者と対照とを比較して，性 年龄を標準化して相対的リスクを算出したるのであ る. $50 \mathrm{rad}$ 以上の群の相対的リスクは1.9で, 統計学的

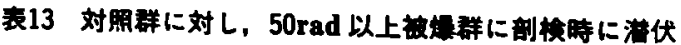 蛒が东在する相対性リスク}

広島（1958－1979）

\begin{tabular}{c|c|c|c}
\hline Dose group & $\begin{array}{c}\text { Number } \\
\text { of autopsy }\end{array}$ & Cases & $\begin{array}{c}\text { Standardized relative risk* } \\
\text { (95\% confidence limits })\end{array}$ \\
\hline $\begin{array}{c}50 \mathrm{rad} \\
\text { or more }\end{array}$ & 341 & 21 & $1.9(1.1-3.2)$ \\
\hline Control & 2495 & 82 & 1.0 \\
\hline
\end{tabular}




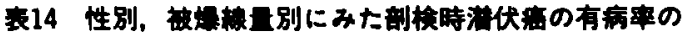
親家数/期待数の比䩙

仏岛（1958－1979）

\begin{tabular}{l|r|r|r|r}
\hline \multirow{2}{*}{ Average dose } & \multicolumn{5}{|c}{ T 65 D tissue total dose in rad } \\
\cline { 2 - 5 } & Control & $1 \sim 49$ & $50 \sim$ & Total \\
\cline { 2 - 5 } & 0 & 9.7 & 134.3 & \\
\hline \multicolumn{5}{|c}{ Male } \\
\hline No. of subjects & 1303 & 762 & 168 & 2233 \\
\hline Obs.(O) & 32 & 17 & 7 & 56 \\
\hline Exp. ${ }^{*}(E)$ & 32.9 & 18.8 & 4.3 & 56.0 \\
\hline O/E & 1.0 & 0.9 & 1.6 & 1.0 \\
\hline
\end{tabular}

Test for significance: $\chi^{2}=1.76$, d.f. $=1, p>0.10$ N.S

* Adjusted for age at death

Female

\begin{tabular}{l|r|r|r|r}
\hline No. of. subjects & 1192 & 827 & 173 & 2192 \\
\hline Obs. (O) & 50 & 35 & 14 & 99 \\
\hline Exp. * (E) & 53.9 & 37.2 & 7.9 & 99.0 \\
\hline \multicolumn{1}{c|}{ O/E } & 0.9 & 0.9 & 1.8 & 1.0 \\
\hline
\end{tabular}

Test for significance : $x^{2}=5.30$, d.f. $=1, p<0.05^{*}$

* Adjusted for age at death
に有意差が認められた。

表14は，性別被爆線量別にみた稓宗数と期待数を比 较し，線旦効果について統計的検定を行った. $50 \mathrm{rad}$ 以 上の群の観察数と期待数の比は，男1.6，女1.8でほほ 等しかったが，統計的有意差は女子のみに認められた。

衣15は，さらに性別，剖検時年龄別，線量別にみた 有病率である，男女共 1-40 rad 群では対照と差を認 めないが, 50rad 以上の群では，約 2 倍の有病率を示し ている。ここで興味深いことは，被爆者です対照群で も死亡時の年龄によって有病率の変らないことであ る。言いかえれば潜伏癌は50歳以下で発生し，以後増 加しないことである. 50 rad 以上の被爆者に多いが,こ れす50歳以下で発生し，その後の增加がないといらこ とになる.

す51つの興味深いことは，男女比である．潜伏癌 の男性の有病率は $2.5 \%$ ，女性のそれは4.5\%で，男女 比は1,8倍女性が多く，被爆者之対照を比整してる男女 差は殆んどない（対照：1.7，被爆者：1.9，…..表15 より算出）これに対し臨床的甲状腺癌は人口10万人対 で男性2.7，女性12.4で，男女比が4.6と女性の比率が

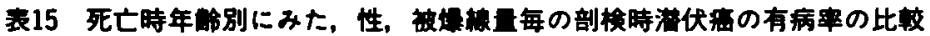

広島（1958-1979）

\begin{tabular}{|c|c|c|c|c|c|c|c|c|c|c|c|c|c|}
\hline \multirow{4}{*}{$\begin{array}{l}\text { Age at } \\
\text { death }\end{array}$} & \multirow{4}{*}{$\begin{array}{l}\text { Average } \\
\text { dose }\end{array}$} & \multicolumn{9}{|c|}{ T 65D tissue total dose in rad } & \multirow{2}{*}{\multicolumn{3}{|c|}{ Total }} \\
\hline & & \multirow{2}{*}{\multicolumn{3}{|c|}{ Control }} & \multirow{2}{*}{\multicolumn{3}{|c|}{$\frac{1 \sim 49}{9.7}$}} & \multirow{2}{*}{\multicolumn{3}{|c|}{$\frac{50 \sim}{134.3}$}} & & & \\
\hline & & & & & & & & & & & \multirow{2}{*}{$\begin{array}{l}\text { Sub- } \\
\text { jects }\end{array}$} & \multirow{2}{*}{ Case } & \multirow{2}{*}{ Rate } \\
\hline & & $\begin{array}{l}\text { Sub- } \\
\text { jects }\end{array}$ & Case & Rate & $\begin{array}{l}\text { Sub- } \\
\text { jects }\end{array}$ & Case & Rate & $\begin{array}{l}\text { Sub- } \\
\text { jects }\end{array}$ & Case & Rate & & & \\
\hline \multicolumn{14}{|c|}{ Male } \\
\hline$<50$ & & 113 & 3 & 2.7 & 68 & 3 & 4.4 & 19 & 2 & 10.5 & 200 & 8 & 4.0 \\
\hline $50 \sim 59$ & & 117 & 3 & 2.6 & 65 & 0 & 0.0 & 21 & 2 & 9.5 & 203 & 5 & 2.5 \\
\hline $60 \sim 69$ & & 395 & 9 & 2.3 & 117 & 7 & 4.0 & 39 & 1 & 2.6 & 611 & 17 & 2.8 \\
\hline $70 \sim 79$ & & 445 & 14 & 3.1 & 291 & 6 & 2.1 & 61 & 2 & 3.3 & 797 & 22 & 2.8 \\
\hline $80 \sim$ & & 233 & 3 & 1.3 & 161 & 1 & 0.6 & 28 & 0 & 0.0 & 422 & 4 & 0.9 \\
\hline Total & & 1303 & 32 & 2.5 & 762 & 17 & 2.2 & 168 & 7 & 4.2 & 2233 & 56 & 2.5 \\
\hline \multicolumn{14}{|c|}{ Female } \\
\hline$<50$ & & 72 & 2 & 2.8 & 54 & 2 & 3.7 & 23 & 2 & 8.7 & 149 & 6 & 4.0 \\
\hline $50 \sim 59$ & & 119 & 5 & 4.2 & 79 & 4 & 5.1 & 19 & 0 & 0.0 & 217 & 9 & 4.1 \\
\hline $60 \sim 69$ & & 261 & 16 & 6.1 & 173 & 7 & 4.0 & 39 & 5 & 12.8 & 473 & 28 & 5.9 \\
\hline $70 \sim 79$ & & 404 & 17 & 4.2 & 286 & 12 & 3.2 & 61 & 5 & 8.2 & 751 & 34 & 4.5 \\
\hline $80 \sim$ & & 336 & 10 & 3.0 & 235 & 10 & 4.3 & 31 & 2 & 6.5 & 602 & 22 & 3.7 \\
\hline Total & & 1192 & 50 & 4.2 & 827 & 35 & 4.2 & 173 & 14 & 8.1 & 2192 & 99 & 4.5 \\
\hline
\end{tabular}

Rate: per 100 subjects 
潜伏癌に比へてて高くなる，又被爆者と対照の間では， 発生率にかなりの差がある(対照：3.2，被爆者：6.9， ……竞8より算出).

これらの事実は，比交的若年時に潜伏瘦が高率に出 来，男女比では女性にわずかに，上り高率であり，こ

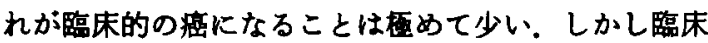
的の癌になるのは女性の割合が明らかに多い，本調查 の大部分が乳頭癌であり，乳頭癌は若い女性に多いの が特改であることより，ある種の女性のホルモンか， promoter となって臨床的の癌になることが推測さ れ，その中です特に被爆者に於いて女性の事の高いこ とは，女性ホルモンと放射線とか， promoter として， 協同して作用する可能性が考えられる。

\section{3. この研究の同䖯点と今後の馀盾}

始めに述べた如く，放射線による甲状腺痁の発生は， 数多くの調査により，略確実とされている。しかし， 個↔の研究を詳しくみると調查内容には，次の上らな 問題点がある.

1) 甲状腺澏は少い疾患であるので，対象集団の人数 が少いと，癌の数も少くなり，1人 2 人の発生の差に よって，結果が大きく変ることとなり，后頼性にそし くなる。

2）対象を大きくとると，その集団から発生する甲状 腺癌を確実にキャッチすることが困䧼となる．甲状腺 癌は比較的予後の良い癌であるため，長い間気付かれ ないでいることも多いので，真の発生率を知ることが むずかしい，又，集団が大きくなる程，放射線以外の 原因によるBiasが多くなりここれを一定にすること が因難である。

厇島での原爆投下は，同時に大集団が放射線をあび たものであるから，放射線の影翼を知る最す適した集 団である．著者等は，広大病院を受診した患者につい て，或いは国民健康保険に入っている人の甲状腺癌に ついて, 被爆距離別に調查し, 何れ子被爆群に統計的 に有意に多いことを発表して来だ).しかし，被爆者の 数は，法律上の被爆者の定義が变る每に増加し，社会 的に，被爆者保護の政策が整5につれて，申請者か増 加した. この基本となる対象人口の変化は，著者等に， 年を追って再調查する気概をそぐすのであった，これ に対して，放影研では合理的な統計処理の出来乃集団 をあらかじめ設定して調查しており，調查対象として 現在行い5る最良のるの考光られる。既に Socolow 等(6) は, 故影研にて1958年以来, 2 年周期で健康診断を 行い，対照を含む集団一成人健康調査対象一を用い，
1958年一1961年までを調査し，13,719人中 14 人の甲状 腺癌を見出し，近距故被爆者で強度の放射線を受けた 者に有意に增加しているとい5結論を得ている，1万 人余の対象であわずか14人の発生では，資料として充 分とは考えられない，その後も類似の研究が時期を異 にして行われているがフー9)，同様の㑯向がある.

本研究は，従来の研究の難点を補5に足るるのを目 標とし，前述の76，758人の放影研の調查集団を対象と し，1958年から1969年に及ふ22年間の長期間に発生し た甲状腺癌を，徹底的に調査をしよらと考光，著者ら が放影研に共同研究を申込み，企画したものである。 可能なあらゆる手段を用いて調查したが，なお $2 〜 3$ の問題が残る。

その 1 つに対象者の全国への払散がある，畽晹登錄 や組織登録は，厷島県のあののみ用いたにすぎず，広 大病院に来る患者す近傍の者が多いため, 遠隔地に住 む対象者の把暒が不充分で，調査から漏れる可能性の あることである。

次には，甲状腺癌の性筫によるすのである，甲状腺 癌の悪性度は組峨型，年龄により大きく異なっている。 租織型については，大部分が乳頭癌であるので問題は ないか，乳頭满は，特に若年者で予後が良く，長い释 過をとるすのである．腫㢆発生から，初診時までの期 間は，各症例毎に大きな差がある．何時診療を受けた といらことにより，何時発生したかといらことが，発 生率をみる上では重要である。幸い本調查では，初め て甲状腺の結穊に気付いた時点を推定発病時として記 録してあるか，推定器病時を基にして珫計をとるため には，期間内に診断されたるのでる，それより前に発 生した症例が多いので,これを除去しなければならず， 又, 調查期間後に発見され，推定発病時が調査期间内 にあるものを含ませねばならないので，実際には出来 ない。しかし，これは重大なことで，もし被溸者より 発生した甲状腺癌と，対照群よりの甲状腺癌との間に

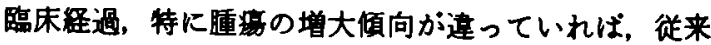
の研究を含めて, 本研究も根本的に見直す必要を生す る. その検討は，別のブロジェクトで行らことを考え ている.

\section{引用文鄚}

1) Hempelman, L.H. : Risk of thyroid neoplasmas after irradiation in childhood. Science $160: 159$ $-163,1968$.

2) Conard, R.A. et al. : Review of medical findings in a Marshallese population twenty-six years after accidental exposure to radioactive fallout. 
BNL-51261, 1980.

3) Milton $R$, Shohoji T : Tentative 1965 radiation dose estimation for atomic bomb survivers, Hiroshima and Nagasaki ABCC TR.68, 1968.

4）加藤一生：原発線量再評価の意義とその動向，原 子力工業28：1-7, 昭57。

5）江崎治夫，重光隆雄：原爆被爆による甲状腺煰の 発生之，その臨床的特異性に荓する研究，広岛医 学, $20 ： 336-347$, 昭42。

6) Socolow El, Hashizume A, Neriishi s, et al.: Thyroid carcinoma in man after exposure to ionizing radiation. A summary of the findings in Hiroshima and Nagasaki. N Engl J Med 268:
$406-410,1963$.

7) Wood JW, Tamagaki $H$, Neriishi $S$, et al.: Thyroid carcinoma in atomic bomb survivors, Hiroshima and Nagasaki Am J Epidemiol 89 : 4 $-14,1969$

8) Parker LN, Belsky JL, YAMAMOTO T, et al : Thyroid carcinoma after exposure to atomic radiation : A continuing survey of a fixed population, Hiroshima and Nagasaki, 1958-76. Ann Intern Med $80:$ 600-604, 1974.

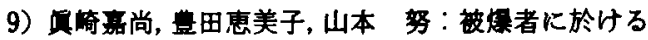
甲状腺癌，広島一長崎, 1958一-1976，厷島医学31： 421-423, 昭53. 